\title{
Menerapkan Strategi Penginjilan Paulus dalam Kisah Para Rasul 17:16-34 pada Penginjilian Suku Auri, Papua
}

\author{
Doni Heryanto ${ }^{1}$, Wempi Sawaki ${ }^{2}$ \\ 1,2Sekolah Tinggi Alkitab Jember, Jember, Jawa Timur \\ 1donheryanto@gmail.com,2wempisawaki@gmail.com
}

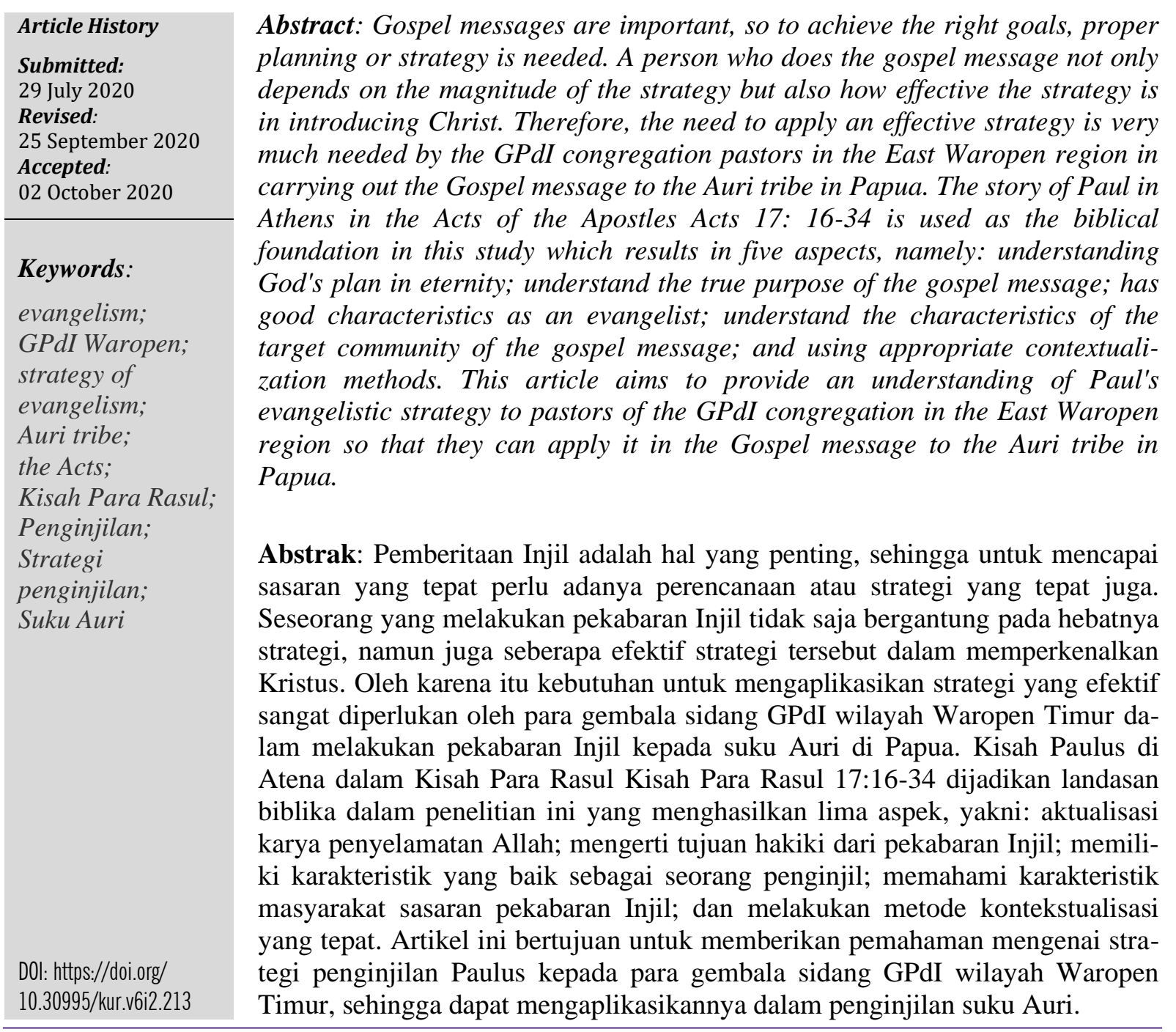

\section{Pendahuluan}

Paulus adalah seorang penginjil terkenal di zaman Perjanjian Baru, di mana ia adalah seorang yang tidak mengikuti Yesus secara langsung seperti Petrus dan kawan-kawan, tetapi justru ia adalah seorang pelaksana Amanat Agung Yesus Kristus yang sangat produktif dalam pekabaran Injil di masa itu. Pertobatan Paulus memiliki implikasi langsung pada keberaniannya 
untuk menjadi pengikut Kristus dan dengan semangat yang berkobar mau mewartakan Injil. ${ }^{1}$ Paulus juga sebagai orang yang berani merintis jemaat di daerah-daerah baru dan dengan penuh hikmat menyatakan kebenaran Allah kepada orang-orang yang yang belum mengenal Allah. Dalam konteks Kisah Para Rasul 17:16-34 Paulus melihat banyak kuil-kuil berhala yang begitu megah dan mewah di Atena. Paulus sedih melihat fenomena seperti itu, dan ia tergerak untuk menyampaikan Injil, supaya mereka mengerti Allah yang tidak dikenal itu. Tidak mudah bagi Paulus untuk menghadapi pola pikir orang Atena yang terkenal fanatik dan kritis itu. Untuk itulah Paulus masuk ke rumah ibadah dan bertukar pikiran dengan orangorang Yahudi yang takut akan Allah. ini merupakan peluang baginya untuk memberitakan Injil. Juga dengan pertolongan Roh Kudus maka Paulus dapat memberitakan Injil kepada masyarakat Atena di Aeropagus, walaupun banyak yang menolak pemberitaan Paulus. Tetapi ada beberapa diantara mereka yang percaya dan menerima Tuhan Yesus sebagai Juruselamat.

Kondisi keberagamaan orang Atena pada masa itu hampir mirip dengan suku Auri di Papua yang menyembah berhala. Suku Auri adalah salah satu dari sekian banyak suku yang hidup di pedalaman Papua. Tradisi hidup dan budaya dari suku Auri yang menyembah kepada pohon besar, gunung, batu, goa, dan beberapa tempat yang dianggap keramat, yang semuanya ini membuat suku Auri sangat sulit diinjili oleh karena kepercayaan-kepercayaan tersebut. Keadaan ini juga dipersulit oleh letak geografis yang sulit dijangkau dan sangat sedikit sekali pekabar Injil yang terbeban secara rutin untuk mengabarkan Injil kepada suku Auri. Gereja Pantekosta di Indonesia (GPdI) wilayah Waropen Timur adalah salah satu gereja yang tergerak untuk mengabarkan Injil kepada suku Auri. Perlu diketahui bahwa GPdI mulai masuk ke Waropen pertama kali pada 3 Januari 1953 dan terus berkembang, dan sejak 1995 terjadi pemekaran dengan terbentuk GPdI wilayah Waropen Timur dan wilayah Waropen Barat. Jarak tempuh dari kabupaten Waropen adalah perjalanan dua hari dengan speedboat dan harus dilanjutkan dengan berjalan kaki. Sungguh medan yang sukar ditempuh kecuali motivasi yang digerakkan oleh kasih kepada jiwa-jiwa yang terhilang. ${ }^{2}$

Oleh karena itu untuk memberitakan kabar baik tentang Yesus Kristus kepada mereka yang belum percaya dibutuhkan strategi yang tepat dan efektif sehingga dapat digunakan secara efisien untuk menjangkau mereka melalui pemberitaan Injil. ${ }^{3}$ Wagner berkata bahwa seorang pekabar Injil harus memiliki strategi yang jelas kepada komunitas yang dituju dan sebelum maju dalam pelayanan pekabaran Injil, mereka mencari tahu segala informasi tentang kondisi kemasyarakatannya, seperti geografis, budaya dan rohani. Ini semua penting demi sebuah strategi yang tepat dan efektif. ${ }^{4}$

Secara umum, berbicara mengenai strategi penginjilan yang dilakukan Paulus dalam Kisah Para Rasul memang mengalami banyak dinamika. Gilbert dan Yogi berpendapat:

${ }^{1}$ A Dan Kia, "Kajian Teologis-Pedagogis Keteladanan Rasul Paulus dalam Penginjilan dan Relevansinya bagi Pendidik Kristen Masa Kini,” Shanan Jurnal Pendidikan Agama Kristen 1, no. 2 (2017): 74-102, http://ejournal.uki.ac.id/index.php/shan/article/view/1493

${ }^{2}$ Fransiskus Irwan Widjaja, "Papua Dan Panggilan Macedonia Di Zaman Millennium Baru," DIEGESIS: Jurnal Teologi Kharismatika 2, no. 1 (2019): 35-38.

${ }^{3}$ Fransiskus Irwan Widjaja, Misiologi Antara Teori, Fakta Dan Pengalaman, 1st ed. (Yogyakarta: Andi Offset, 2018).

${ }^{4}$ Peter Wagner, Strategi Perkembangan Gereja (Malang: Gandum Mas, 2015), 13 
Rasul Paulus memiliki peran yang besar bagi perkembangan kekristenan pada jemaat mula-mula. Rasul Paulus sebagai rasul yang ditetapkan oleh Allah untuk pergi keluar dari Israel dan pergi ke bangsa-bangsa lain, memiliki jangkauan yang lebih luas dengan berbagai dinamika di dalamnya, dimana sudah pasti akan menemukan perbedaan budaya, pola pikir dan lain sebagainya dan seiring dengan hal itu tentunya ada banyak tantangan yang membutuhkan strategi jitu dalam mengabarkan Injil. ${ }^{5}$

Tidak dapat dipungkiri bahwa pada masa pelayanan rasul Paulus, ada orang yang tidak suka dengan Paulus, termasuk orang-orang Yahudi yang ingin membunuhnya dan orang nonYahudi yang membencinya juga. Beberapa kali Paulus harus menghadapi tantangan dan ancaman, dan kesemuanya itu butuh strategi yang tepat untuk dapat mengkomunikasikan Injil secara lintas budaya.

Strategi dalam sebuah pekabaran Injil sangat penting untuk dipelajari, apalagi jika sedang bermisi di dalam konteks budaya yang berbeda. Oleh sebab itu, dalam konteks penelitian ini, strategi penginjilan Paulus dalam Kisah Para Rasul 17:16-34 akan dianalisa guna mendapatkan prinsip untuk dapat diaplikasikan bagi para gembala sidang GPdI wilayah Waropen Timur dalam menginjili suku Auri. Itu sebabnya, pembahasan ini memiliki kepentingan untuk mempertimbangkan berbagai fenomena yang berkaitan situasi dan kondisi di lapangan.

\section{Metode Penelitian}

Penelitian dilakukan dengan menggunakan metode bersifat kualitatif dengan pendekatan deskriptif. Artinya, data dan fakta yang dihimpun lebih berbentuk kata atau gambar daripada angka-angka. Mendeskripsikan yang dimaksud di sini berarti menggambarkan apa, mengapa, dan bagaimana suatu kejadian terjadi. ${ }^{6}$ Selain itu, dalam peneltian ini juga mengklasifikasikan strategi penginjilan Paulus berdasarkan Kisah Para Rasul 17:16-34, sehingga didapati beberapa poin utama yang akan digunakan sebagai acuan wawancara.

Penelitian dilakukan dalam dua tahapan dalam pengumpulan data, yaitu: pengumpulan data awal dan pengumpulan data utama. Pengumpulan data awal dilakukan melalui observasi, yaitu metode pengamatan yang mengharuskan peneliti turun ke lapangan mengamati hal-hal yang berkaitan dengan subyek penelitian (gembala sidang GPdI Wilayah Waropen Timur Papua). Pada tahap ini masih menggali informasi yang bersifat awal untuk memetakan masalah. Sementara metode pengumpulan data utama yang digunakan dalam penelitian ini, yaitu melalui wawancara kepada 9 gembala sidang GPdI wilayah Waropen Timur Papua. Waktu pelaksanaan wawancara pada bulan Juni sampai Oktober 2019.

Data dari hasil wawancara kepada 9 para gembala sidang GPdI Wilayah Waropen Timur Papua dikelompokkan berdasarkan lima subfokus, yakni aktualisasi karya penyelamatan Allah, mengerti tujuan hakiki dari pekabaran Injil, memiliki karakteristik yang baik sebagai seorang penginjil, memahami karakteristik masyarakat sasaran pekabaran Injil, dan melakukan metode kontekstualisasi yang tepat. Hasil yang diperoleh kemudian diolah dan disimpul-

${ }^{5}$ Gilbert Yasuo Imanuel and Yogi Darmanto, "Pelayanan Lintas Budaya: Sebuah Kajian Tentang Pelayanan Rasul Paulus Dalam Kisah Para Rasul 16: 13-40," VOX DEI: Jurnal Teologi Dan Pastoral 1, no. 1 (2020): 78-89, https://jurnal.sttekumene.ac.id/index.php/VoxDei/article/view/18

${ }^{6}$ Aan Satori, Djaman, dan Komariah, Metodologi Penelitian Kualitatif (Bandung: Alfabeta, 2010), 28 
kan untuk mendapatkan aplikasi bagi gembala sidang GPdI wilayah Waropen Timur dalam mengijili suku Auri.

Kegiatan penginjilan sebenarnya sudah masuk sejak tahun 1990-an di wilayah suku Auri oleh Gereja Injili di Indonesia (GIdI), dan telah ada perintisan Pos PI Gereja Pantekosta di Indonesia (GPdI) sejak tahun 2008 dan hingga saat ini sudah ada beberapa orang yang percaya kepada Yesus Kristus. Namun, penginjilan kepada suku Auri terbilang memiliki halangan yang besar karena mereka mendasari kepercayaannya kepada mitos nenek moyang yang dibangunnya dalam bentuk adat istiadat dengan cara menyembah kepada pohon, batu, goa. Cara mereka menyembah adalah secara perorangan dan pekerjaan mereka adalah berburu, dimana sebelum berburu mereka memanjat pohon untuk mendapat kekuatan untuk berburu. Jumlah jiwa di kampung suku Auri adalah sekitar 1500 orang, dan diapit oleh sukusuku yang berbeda di kampung sekitarnya.

\section{Hakikat Strategi Penginjilan}

Secara definisi, kata strategi memiliki pengertian siasat atau akal dalam kerangka mencapai suatu tujuan. Istilah strategi sendiri berasal dari kata Yunani strategos yang secara harfiah diterjemahkan sebagai jenderal yang mengatur pergerakan militer pada zaman demokrasi Athena. ${ }^{7}$ Tentu saja dari istilah ini maka akan berkembang pengertian strategi berkaitan dengan rancangan, nalar pemikiran yang logis, dan etis, terkait dalam hal melakukan dan mengusahakan pencapaian-pencapaian maksimal yang terkait dengan sebuah pemenuhan perencanaan. ${ }^{8}$ Sedangkan penginjilan didefinisikan sebagai penyampaian kabar baik. Maksud dari pekabaran Injil adalah untuk memberi kesempatan kepada semua orang, kesempatan yang memadai untuk menerima Yesus Kristus sebagai Juruselamat dan melayaniNya dalam persekutuan dengan gereja-Nya. ${ }^{9}$ Orang Kristen yang mengkhususkan diri dalam penginjilan dikenal sebagai penginjil, baik itu mereka yang berada di komunitas asal mereka atau hidup sebagai misionaris di lapangan.

Sejak semula penyelamatan Allah terus dinyatakan dengan memberikan janji kepada Abraham sampai keturunannya bahwa Allah akan membuat Abraham menjadi bangsa yang besar dan akan memberkati kemanapun pergi. Penyelamatan Allah juga dinyatakan melalui pembebasan bangsa Israel dari perbudakan di Mesir. Artinya, Allah menginginkan setiap umat-Nya memperoleh keselamatan dari pada-Nya, dan Allah juga melibatkan umat-Nya yang sudah diselamatkan untuk membagikan keselamatan itu bagi manusia yang belum diselamatkan. Dalam konteks melakukan penginjilan akan banyak tantangan yang harus dihadapi seperti bahasa, adat-istiadat, politik, dan sistem kepercayaan dalam masyarakat. Tantangan ini sering menjadi penghambat dalam memberitakan Injil. Melihat permasalahan tersebut dibutuhkan strategi yang tepat untuk menyampaikan pesan Injil. Venema mengatakan bahwa injil Kristus harus dibawa dan diberitakan kepada manusia dalam keadaan yang konkrit sebagaimana adanya, karena setiap orang memiliki pola dan kebiasaan budayanya masing-masing. ${ }^{10}$

\footnotetext{
${ }^{7}$ Wilbert R Shenk, Mission Strategies (Grand Rapids: Michigan, 1993), 218

${ }^{8}$ WJS Poerwadarminta, Kamus Umum Bahasa Indonesia (Jakarta: Balai Pustaka, 1996), 246

${ }^{9}$ Peter Wagner, Strategi Perkembangan Gereja (Malang: Gandum Mas, 2015), 12

${ }^{10} \mathrm{H}$. Venema, Injil Untuk Semua Orang, Pembimbing ke Dalam Ilmu Misiologi, Jilid I (Jakarta: Yayasan Komunikasi Bina Kasih, 1997), 32
} 
Dari pengertian di atas maka dijabarkan tentang strategi penginjilan. Strategi penginjilan adalah perencanaan yang digunakan seseorang untuk memberitakan Injil. Strategi penginjilan merupakan sebuah kekuatan yang menunjang seorang pemberita Injil dalam melakukan penginjilan secara efektif dan tepat sasaran. ${ }^{11}$ Karena penginjilan adalah tanggung jawab setiap orang percaya, maka penginjilan harus terus dilakukan. ${ }^{12}$ Walaupun dalam penginjilan akan banyak halangan dan halangan inilah yang akan memadamkan semangat dalam diri orang percaya, maka penggunaan strategi yang tepat akan membantu seorang penginjil dalam mengerahkan segala upaya yang mereka punya dalam mengabarkan berita Injil dengan metode dan perencanaan yang tepat. Strategi penginjilan bukan saja memberi arah dan rencana untuk sebuah pelayanan penginjilan, tetapi juga sebagai keseluruhan daya penggerak di dalam seluruh aktivitas pekabaran Injil. Kalau strategi adalah daya penggerak dalam hidup seseorang, maka sebuah strategi harus terus dihidupkan dan dimatangkan demi tercapainya sebuah sasaran yang baik. ${ }^{13}$

\section{Deskripsi Singkat Kisah Para Rasul 17:16-34}

Kisah Para Rasul merupakan bagian dari Perjanjian Baru yang ditempatkan sesudah keempat Injil. Secara umum para ahli biblika menyetujui bahwa kitab Kisah Para Rasul ditulis oleh Lukas yang juga adalah penulis Injil Lukas. Memang tidak disebut secara langsung nama Lukas pada awal kitab ini, namun frasa "Hai Teofilus, dalam bukuku yang pertama" di ayat pertama kitab ini, merupakan indikasi kuat yang merujuk bahwa ada hubungan kitab ini dengan Injil Lukas dimana dari keempat Injil, hanya kitab Lukas yang dalam alamat penulisannya ditujukan kepada Teofilus, nama yang sama disebut dalam Kisah Para Rasul. ${ }^{14}$ Lukas menulis untuk meyakinkan Teofilus bahwa "segala sesuatu yang diajarkan kepadamu sungguh benar" (band. Luk. 1:4). Teofilus mungkin adalah orang bukan Yahudi yang bertobat menjadi orang Kristen, dan Lukas menulis untuk memberikan kepadanya banyak pengetahuan tentang asal mula Kekristenan ketimbang yang sudah dimilikinya. Termasuk di dalamnya ialah kisah tentang kehidupan, kematian dan kebangkitan Yesus (Injil), serta pendirian dan perluasan gereja pada amsa itu.

Waktu penulisan Kitab Kisah Para Rasul tidak dapat dipastikan, namun demikian beberapa ahli biblika memperkirakan jika kitab ini ditulis sekitar tahun $62^{15}$, dengan pertimbangan pemerintahan Nero yang saat itu (64-65) mendatangkan kesusahan dan penganiayaan besar bagi jemaat mula-mula. Namun, tidak tercatatnya kisah tentang pemenjaraan Paulus yang kedua hingga kematiannya, dan kematian Yakobus sebagai martir (menurut Yosepus sekitar tahun 62 M.), serta peristiwa kejatuhan Yerusalem (70 M), dapat diduga juga jika penulisan Kisah Para Rasul bisa lebih awal dari semua peristiwa tersebut. ${ }^{16}$

\footnotetext{
${ }^{11}$ Silas Sariman, "Strategi Misi Sadrach Suatu Kajian yang Bersifat Sosio Historis," Jurnal ABDIEL 3, no. 1 (2019): 17-32, http://journal.stt-abdiel.ac.id/JA/article/view/34/22

${ }^{12}$ Fransiskus Irwan Widjaja, Daniel Ginting, and Sabar Manahan Hutagalung, "Teologi Misi Sebagai Teologi Amanat Agung,” THRONOS: Jurnal Teologi Kristen 1, no. 1 (2019): 17-24.

${ }^{13}$ Martin Handako, Motivasi Daya Penggerak Tingkah Laku (Yogyakarta: Kanisius, 1992), 19

${ }^{14}$ Merril C.Tenney, Survei Perjanjian Baru (Malang: Gandum Mas, 1993), 284

${ }^{15}$ William Barclay, Pemahaman Alkitab Setiap Hari: Kitab Kisah Para Rasul (Jakarta: BPK Gunung Mulia, 2009), 3

${ }^{16}$ John MacArthur, The MacArthur Study Bible (USA: Thomas Nelson, 2006), 1596
} 
Kisah Para Rasul dapat dikatakan sebagai sebuah kisah sejarah perjalanan pemberitaan injil tentang Yesus, mulai dari Yerusalem dan berakhir di pusat dunia, yang adalah kota Roma. Harls Evan Siahaan juga berpendapat bahwa hampir tidak ada bantahan jikalau dikatakan bahwa Kisah Para Rasul merupakan kitab bernuansa sejarah. Hal ini dimaklumi karena seluruh kitab ini menceritakan rangkaian kejadian yang berkaitan dengan kehadiran gereja Tuhan serta persebarannya di sekitar Timur Tengah pada saat itu. Perlu juga ditambahkan bahwa karakter unitas Lukas-Kisah Para Rasul telah membuktikan adanya kontinuitas peneltian dari sang ilmuwan tentang catatan sejarah. ${ }^{17}$ Lukas, sebagai penulis Kisah Para Rasul bermaksud memberikan kisah dari asal mula dan perkembangan gereja yang begitu pesat melalui karya Roh Kudus; yang dimulai dari Kisah Para Rasul 1:8 dan dilanjutkan keseluruh bagian dalam kitab ini.

Kisah Para Rasul 17:16-34 adalah bingkai yang digunakan dalam penelitian ini dan Paulus di Atena merupakan inti kisah yang merupakan sebuah pengalaman pekabaran Injil yang cukup menantang dan sulit, karena di kota ini Paulus akan menemui banyak kaum cendekiawan, pemikir hebat, dan filsuf-filsuf yang buah pikir mereka mempengaruhi kebudayaan, kemajuan teknologi,dan peradaban. Selain itu, Atena dikenal juga sebagai kota seribu dewa, dimana hampir di setiap ruas jalan terdapat patung para dewa, sehingga tidak heran ada sebuah gurauan yang mengatakan bahwa di Atena lebih mudah menjumpai patung dewa dibandingkan manusia. ${ }^{18}$

Kisah Paulus dalam Kisah Para Rasul 17:16-34 ini dicatat oleh Lukas pada perjalanan misi Paulus kedua. Latar belakang terjadinya kisah di Atena ini adalah bermula dari huru-hara yang diadakan oleh orang-orang Yahudi di Tesalonika terhadap tim misi Paulus, karena di sana Paulus dan Silas berhasil memberitakan Injil tentang Yesus Kristus dan banyak orang Yunani yang akhirnya mau percaya kepada pemberitaan Paulus dan Silas. Keberhasilan mereka ini membuat ketidaksukaan dari orang-orang Yahudi setempat yang berusaha membuat keributan dan ingin menangkap Paulus. Namun rencana ini dapat diketahui olehpengikut Paulus, sehingga mereka meminta agar Paulus melarikan diri ke Berea. Peristiwa inilah yang akhirnya mengantarkan Paulus tiba di kota Atena juga.

Di Atena Rasul Paulus memulai pemberitaannya dengan apa yang dipikirkan oleh pendengarnya (Kis. 17:16-34). Di depan sidang Aeropagus, Paulus membuka pembicaraan dengan membahas "allah yang tidak di kenal". Topik ini tentu membuat tertarik semua anggota yang hadir di Aeropagus. Tidak lupa pula bahwa Atena adalah pusat kajian filsafat pada waktu itu. Berbagai macam mazhab filsafat tumbuh subur di kota itu, seperti golongan atau kelompok Epikuros dan aliran Stoa. Di Atena rasanya semua orang sibuk untuk berpikir, berfilsafat, dan mencari tahu hal-hal baru, sehingga kehadiran Paulus dengan berita baru yang dibawanya mampu menarik hati orang-orang Atena dan Paulus dengan sangat cerdik memanfaatkan keingintahuan mereka. Memang dalam proses pekabaran Injil di Atena, Paulus masuk dari pola pikir dari para pendengar yaitu tentang allah mereka. Namun Rasul Paulus tetap

\footnotetext{
${ }^{17}$ Harls Evan R. Siahaan, "Presuposisi Kitab Kisah Para Rasul Dalam Rancang Bangun Teologi Pentakosta," Kurios 4, no. 1 (April 11, 2018): 56-73, accessed April 20, 2018, http://www.sttpb.ac.id/ejournal/index.php/kurios/article/view/34/48.

${ }^{18}$ J.Knox Chamblin, terj. Irwan Tjulianto dan Elsye Elisabeth Rau, Paulus dan Diri (Surabaya: Momentum, 2009), 21
} 
mempertahankan inti dari berita yang dia bawa yaitu Tuhan Yesus Kristus yang mati dan bangkit untuk keselamatan manusia.

\section{Pembahasan}

\section{Aktualisasi Karya Penyelamatan Allah}

Alkitab menandaskan bahwa semua manusia telah berdosa dan kehilangan kemuliaan Alah dan setiap dosa akan menerima akibat hukuman maut. Oleh sebab itu tanpa aktualisasi rencana dan karya penyelamatan dari Allah, semua manusia akan berujung kepada maut secara kekal. Namun perlu dipahami bahwa manusia tidak mampu menyelamatkan dirinya sendiri. Konsep mengenai aktualisasi karya penyelamatan Allah adalah hanya Allah saja Pribadi satusatunya yang memprakarsai keselamatan untuk manusia. Ia menjadi manusia melalui Yesus Kristus, taat sampai mati di kayu salib menjadi jalan penebusan bagi orang berdosa. Allah telah menyediakan rencana keselamatan-Nya bagi manusia, dan satu-satunya cara masuk kedalamnya adalah dengan menerimanya melalui iman kepada Yesus.

Dalam strategi dan berita penginjilannya, Paulus menempatkan Kristus sebagai sentral dari segala aktivitas yang dilakukan oleh Allah. Inisiatif untuk mencipta dan kuasa penciptaan bersumber dari Kristus. Semua hukum dan kehendak yang mengatur segala ciptaan dan pemerintahan di dalam alam semesta, ada di dalam rencana Allah melalui Yesus Kristus. Berikut ini adalah pengelompokkan aktualisasi karya penyelamatan Allah sebagai bagian dari strategi penginjilan Paulus berdasarkan Kisah Para Rasul 17:16-34:

\begin{tabular}{|c|c|l|}
\hline \multirow{3}{*}{$\begin{array}{c}\text { Aktualisasi karya } \\
\text { penyelamatan Allah }\end{array}$} & 1 & Keberdosaan manusia (Kis 17: 22, 32) \\
\cline { 2 - 3 } & 2 & Wujud kasih dan keadilan Allah (Kis. 17:31) \\
\cline { 2 - 3 } & 3 & Yesus membawa berita Injil kepada manusia (Kis. 17:30) \\
\cline { 2 - 3 } & 4 & Yesus satu satunya Juruselamat (Kis. 17:31) \\
\hline
\end{tabular}

\section{Mengerti tujuan hakiki dari pekabaran Injil}

Injil adalah kabar baik yang berintikan berita mengenai Tuhan Yesus Kristus sebagai Juru selamat dunia dan tidak ada keselamatan di luar Yesus Kristus. Oleh karena itu, Yesus adalah Anak Tunggal Allah yang diutus ke dunia sebagai Penebus bagi manusia yang tidak berpengharapan dan telah kehilangan kemuliaan untuk dibuat-Nya kembali kedalam persekutuan dengan Allah melalui Dia. Sesuai amanat dalam Alkitab tujuan utama penginjilan adalah memuliakan nama Tuhan. Itu berarti memberitakan Injil kepada semua bangsa di dunia supaya nama Tuhan menerima kembali kemuliaan yang sepatutnya. ${ }^{19}$ Banyak tantangan yang akan ditemui oleh seorang pekabar Injil, namun strategi yang tepat akan mampu menolong membuat pekabaran Injil menjadi lebih efektif. Strategi memang penting, namun di atas segalanya mengerti tentang tujuan hakiki dadi penginjilan tidak kalah penting juga, sebab jika pemahaman awal dari seorang penginjil tentang tujuan mengapa harus menginjil sudah salah, maka apa yang dia lakukan juga akan sia-sia dan berujung pada kegagalan. Berikut ini adalah pengelompokkan mengerti tujuan hakiki dari pekabaran Injil sebagai bagian dari strategi penginjilan Paulus berdasarkan Kisah Para Rasul 17:16-34:

${ }^{19}$ Venema, 216 


\begin{tabular}{|l|c|l|}
\hline \multirow{4}{*}{$\begin{array}{c}\text { Mengerti tujuan hakiki } \\
\text { dari pekabaran Injil }\end{array}$} & 5 & Mewujudkan rencana Allah (Kis. 17:26-27) \\
\cline { 2 - 3 } & 6 & Menyelamatkan orang berdosa (Kis. 17:30) \\
\cline { 2 - 3 } & 7 & Memberitakan kabar baik (Kis 17:18,31) \\
\cline { 2 - 3 } & 8 & Mengajak orang bertobat (Kis. 17:30) \\
\cline { 2 - 3 } & 9 & Mengajar kebenaran (Kis. 17:29) \\
\cline { 2 - 3 } & 10 & Memuridkan semua bangsa (Kis. 17:34) \\
\hline
\end{tabular}

\section{Memiliki Karakteristik yang Baik sebagai Seorang Penginjil}

Rasul Paulus adalah seorang rasul yang berani menyatakan kebenaran Allah kepada setiap orang yang ia jumpai. Hampir setiap pelayanan penginjilan rasul Paulus menuai keberhasilan yang luar biasa dimana ia dapat membuat orang-orang untuk berbalik dan percaya kepada Tuhan Yesus Kristus. Dari misi yang dilakukan Paulus lahir banyak misionaris Injil yang baru. Tentu Roh Kuduslah yang bekerja dalam kehidupan Paulus dan dalam setiap pemberitaan atau penginjilannya. Hal lain yang mendukung kesuksesan karya penginjilan itu adalah pola atau strategi rasul Paulus dalam melaksanakan karya misinya. Perencanaan yang hebat disertai kuasa Roh Kudus menghasilkan tuaian yang besar dalam misi itu. Rasul Paulus mengetahui kebenaran Atena yang begitu sukar menerima Injil keselamatan. Sekalipun demikian rasul Paulus tetap giat dalam pemberitaan Injil, dan ia memiliki karakteristik yang baik sebagai seorang penginjil yang efektif, seperti halnya para rasul dan jemaan mula-mula. ${ }^{20}$ Paulus adalah seorang pintar, menguasai budaya Yahudi dan juga warga Negara Roma. Yesus tahu dia akan sanggup menceritakan injil kepada banyak orang karena dia bisa masuk ke semua tingkatan dan golongan, karena selain berwawasan luas, ia juga memiliki karakteristik yang mumpuni sebagai seorang pemberita Injil. Berikut ini adalah pengelompokkan memiliki karakteristik yang baik sebagai seorang penginjil sebagai bagian dari strategi penginjilan Paulus berdasarkan Kisah Para Rasul 17:16-34:

\begin{tabular}{|c|c|l|}
\hline \multirow{2}{*}{$\begin{array}{c}\text { Memiliki karakteristik } \\
\text { yang baik sebagai } \\
\text { seorang penginjil }\end{array}$} & 11 & $\begin{array}{l}\text { Penuh dengan keberanian oleh Roh Kudus } \\
\text { (Kis.17:22) }\end{array}$ \\
\cline { 2 - 3 } & 12 & $\begin{array}{l}\text { Memiliki hati yang terbeban terhadap } \\
\text { keselamatan orang lain (Kis. 17:16) }\end{array}$ \\
\cline { 2 - 3 } & 13 & Berwawasan luas (Kis.17:18) \\
\hline
\end{tabular}

\section{Memahami Karakteristik Masyarakat Sasaran Pekabaran Injil}

Pokok permasalahan Rasul Paulus di Atena adalah karena ia menjumpai banyaknya penyembahan berhala (Kis. 17:16). Untuk itu dia mulai melakukan pendekatan dengan cara bertukar pikiran untuk dapat memahami sifat dan karakter mereka. Dalam penginjilannya di Atena, Rasul Paulus melepaskan jubah ke Yahudiannya dan memahami karakteristik budaya lokal agar Injil bisa dikomunikasikan kepada orang-orang Atena, seperti yang dikatakan oleh Tomatala bahwa Paulus memakai metode pendekatan akomodasi, yaitu sikap memahami dan menghargai atau sikap terbuka terhadap kebudayaan asli yang dilakukan dalam sikap, kelakuan, dan pendekatan praktis, dalam tugas misionaris baik secara teologi maupun ilmiah. Objek akomodasi adalah kehidupan budaya yang menyeluruh dalam suatu bangsa baik dari segi fisik, sosial, idealisme. ${ }^{21}$ Komunikasi lintas budaya tidak hanya sekedar masalah bahasa,

\footnotetext{
${ }^{20}$ Harls Evan Siahaan, "Karakteristik Pentakostalisme Menurut Kisah Para Rasul,” Dunamis: Jurnal Teologi dan Pendidikan Kristiani 2, no. 1 (2017): 12-28.

${ }^{21}$ Y. Tomatala. Penginjilan Masa Kini II (Gandum Mas Malang 1998), 77-78
} 
tetapi sangat terkait dengan budaya dan worldview dari para pelaku yang terlibat komunikasi tersebut. Ini adalah sesuatu yang sangat penting karena untuk membuat sebuah komunikasi lintas budaya bisa menjadi lebih efektif diperlukan pemahaman budaya dari setiap pelaku yang terlibat dalam proses komunikasi. Berikut ini adalah pengelompokkan melakukan memahami karakteristik masyarakat sasaran pekabaran Injil sebagai bagian dari strategi penginjilan Paulus berdasarkan Kisah Para Rasul 17:16-34:

\begin{tabular}{|c|c|l|}
\hline $\begin{array}{c}\text { Memahami karakteristik } \\
\text { masyarakat sasaran } \\
\text { pekabaran Injil }\end{array}$ & 14 & Memahami karakteristik orang Atena (Kis 17:17) \\
\cline { 2 - 3 } & 16 & Memahami kondisi geografis Atena (Kis. 17:17, 23) \\
\hline
\end{tabular}

\section{Melakukan metode kontekstualisasi yang tepat}

Di tengah-tengah dunia yang berbudaya majemuk dan dengan segala perkembangan dan pergumulannya, gereja Tuhan ditantang untuk selalu menjadi terang dan garam dunia. Tidak ada alasan bagi umat-Nya untuk tidak menjadi seperti yang diharapkan oleh Tuhan. Di sini Injil harus diberitakan sesuai dengan kebutuhan zaman dan konteks yang berlaku. Keberhasilan Rasul Paulus dalam penginjilannya karena menggunakan strategi kontestual yaitu pendekatan budaya terhadap orang-orang yang ia jumpai. Demikian juga pelayanan penginjilan yang dilakukannya Paulus di Atena dalam konteks Kisah Para Rasul 17:16-34 di mana ia melakukan pendekatan-pendekatan kepada orang-orang Atena dengan cara bertukar pikiran dengan orang-orang Yahudi dan orang-orang yang takut akan Allah. Setiap hari ia berdialog dengan orang-orang yang ia jumpai di pasar, dan juga beberapa ahli pikir dan dari golongan Epikuros dan Stoa dan juga hadir di Aeropagus untuk menjelaskan Injil. Melakukan metode kontekstualisasi yang tepat dibagi dalam beberapa aspek. Berikut ini adalah pengelompokkan melakukan metode kontekstualisasi yang tepat sebagai bagian dari strategi penginjilan Paulus berdasarkan Kisah Para Rasul 17:16-34:

\begin{tabular}{|c|c|l|}
\hline \multirow{1}{*}{\begin{tabular}{c} 
Melakukan metode $\begin{array}{c}\text { Mente } \\
\text { kontekstualisasi yang tepat }\end{array}$ \\
\cline { 2 - 3 }
\end{tabular}} & 18 & $\begin{array}{l}\text { Menyatakan Allah yang tidak dikenal (Kis. 17:23) } \\
\text { menyelamatkan (Kis. 17:24-27) }\end{array}$ \\
\cline { 2 - 3 } & 19 & $\begin{array}{l}\text { Memahami bentuk interaksi komunikasi Injil } \\
\text { (Kis. 17:22-24) }\end{array}$ \\
\cline { 2 - 3 } & 20 & $\begin{array}{l}\text { Bertukar pikiran dengan orang-orang setempat } \\
\text { (Kis. 17:17) }\end{array}$ \\
\hline
\end{tabular}

Setelah seluruh data tentang strategi penginjilan Paulus menurut Kisah Para Rasul 17:16-34 dapat di analisis dengan metode wawancara, maka ditemukan pemahaman dan aplikasi dari para gembala sidang GPdI di Wilayah Waropen Timur Papua, khususnya sembilan partisipan yang diteliti adalah sebagai berikut:

Seluruh partisipan atau sembilan gembala sidang GPdI di Wilayah Waropen Timur Papua yang diteliti, memahami strategi penginjilan Paulus dalam Kisah Para Rasul 17:16-34 tetapi tidak atau belum mengaplikasikannya secara khusus dalam program penginjilan kepada suku Auri.

Lima dari sembilan partisipan atau gembala sidang GPdI di Wilayah Waropen Timur Papua yang diteliti, memahami strategi penginjilan Paulus dalam Kisah Para Rasul 17:16-34 tetapi merasakan kesulitan ketika harus menginjili suku Auri dikarenakan letak geografis yang sulit dijangkau serta membutuhkan biaya yang sangat besar. 
Seluruh partisipan atau sembilan gembala sidang GPdI di Wilayah Waropen Timur Papua yang diteliti memahami karakteristik suku Auri dan urgensi penginjilan kepada suku Auri.

\section{Menerapkan Strategi Penginjilan Paulus}

Dari lima aspek strategi penginjilan Paulus dalam Kisah Para Rasul 17:16-34 dari hasil penelitian melalui metode wawancara yang telah menunjukkan pemahaman para gembala sidang GPdI di Wilayah Waropen Timur Papua, maka dihasilkan aplikasi yang sifatnya terapan dan kiranya menjadi usulan guna direfleksikan bersama oleh para gembala sidang GPdI di Wilayah Waropen Timur Papua, sebagai berikut:

\begin{tabular}{|c|c|c|}
\hline No & $\begin{array}{c}\text { Strategi } \\
\text { Penginjilan Paulus }\end{array}$ & Aplikasi \\
\hline \multirow{3}{*}{1.} & \multirow{3}{*}{$\begin{array}{l}\text { Aktualisasi karya } \\
\text { penyelamatan } \\
\text { Allah }\end{array}$} & $\begin{array}{l}\text { Sebagai seorang pekabar Injil harus menyadari bahwa keberdosaan } \\
\text { manusia adalah problem utama dalam hidup manusia }\end{array}$ \\
\hline & & $\begin{array}{l}\text { Sebagai seorang pekabar Injil harus menyadari bahwa Allah itu adil } \\
\text { dalam menghukum orang berdosa namun Ia juga kasih, yaitu dengan } \\
\text { menyediakan jalan pengampunan }\end{array}$ \\
\hline & & $\begin{array}{l}\text { Sebagai seorang pekabar Injil harus menyadari bahwa satu-satunya yang } \\
\text { dapat menyelamatkan manusia dari dosa hanyalah melalui Yesus Kristus }\end{array}$ \\
\hline \multirow{4}{*}{2.} & \multirow{4}{*}{$\begin{array}{l}\text { Mengerti tujuan } \\
\text { hakiki dari } \\
\text { pekabaran Injil }\end{array}$} & Menyelamatkan orang berdosa adalah tujuan utama dan tertinggi \\
\hline & & $\begin{array}{l}\text { Memberitakan kabar baik tentang Yesus Kristus adalah sebuah } \\
\text { keharusan }\end{array}$ \\
\hline & & $\begin{array}{l}\text { Mengajak orang untuk bertobat harus menjadi sasaran utama dalam } \\
\text { penginjilan }\end{array}$ \\
\hline & & $\begin{array}{l}\text { Mengajar orang dalam kebenaran dan memuridkan harus dilakukan } \\
\text { ketika seseorang sudah bertobat }\end{array}$ \\
\hline \multirow{3}{*}{3.} & \multirow{3}{*}{$\begin{array}{l}\text { Memiliki } \\
\text { karakteristik yang } \\
\text { baik sebagai } \\
\text { seorang penginjil }\end{array}$} & $\begin{array}{l}\text { Seorang penginjil haruslah menggantungkan hidupnya dalam pimpinan } \\
\text { kuasa Roh Kudus }\end{array}$ \\
\hline & & $\begin{array}{l}\text { Seorang penginjil harus memiliki beban dan hasrat kepada komunitas } \\
\text { yang ia injili }\end{array}$ \\
\hline & & $\begin{array}{l}\text { Seorang penginjil harus memiliki wawasan yang luas yang dapat } \\
\text { digunakan untuk berapologetika }\end{array}$ \\
\hline \multirow{3}{*}{4.} & \multirow{3}{*}{$\begin{array}{l}\text { Memahami } \\
\text { karakteristik } \\
\text { masyarakat sasaran } \\
\text { pekabaran Injil }\end{array}$} & $\begin{array}{l}\text { Memahami karakteristik (sosial, keagaamaan, adat, budaya) dari } \\
\text { komunitas yang akan diinjili adalah sebuah keharusan }\end{array}$ \\
\hline & & $\begin{array}{l}\text { Memahami kondisi geografis dari komunitas yang akan diinjili adalah } \\
\text { sebuah keharusan }\end{array}$ \\
\hline & & $\begin{array}{l}\text { Perlu memperhatikan momentum yang tepat mengenai kapan harus } \\
\text { mulai memberitakan Injil dan kapan harus merencanakan strategi baru }\end{array}$ \\
\hline \multirow{3}{*}{5.} & \multirow{3}{*}{$\begin{array}{l}\text { Melakukan metode } \\
\text { kontekstualisasi } \\
\text { yang tepat }\end{array}$} & Menggunakan dialog sebagai strategi pemberitaan Injil \\
\hline & & $\begin{array}{l}\text { Menggunakan strategi common ground untuk dijadikan jembatan } \\
\text { pengabaran Injil }\end{array}$ \\
\hline & & $\begin{array}{l}\text { Menggunakan strategi komunikasi yang baik dan disesuaikan dengan } \\
\text { kondisi masyarakat yang diinjili }\end{array}$ \\
\hline
\end{tabular}

Pada akhirnya, dari kisah Paulus di Atena, bisa dipelajari bahwa pendekatan ke dalam masyarakat yang akan diinjili membutuhkan sebuah strategi yang tidak kaku dan tidak harus terpaku dalam sebuah cara baku, bahkan Paulus dengan cerdiknya mampu memakai cara yang sangat kontekstual yang dapat dipahami pendengarnya kala itu. Sebagai pemberita Injil harus jeli dalam melihat strategi-strategi tertentu yang dapat diaplikasikan guna kabar Injil dapat dicerna dan dimengerti oleh pendengarnya, dan tentu saja pemberita Injil harus kreatif, inovatif, dan mampu melihat dari banyak perspektif. 


\section{Kesimpulan}

Terdapat lima aspek penting yang ditemukan dalam Kisah Para Rasul 17:16-34 mengenai strategi penginjilan yang telah dilakukan oleh Paulus di Atena, yakni: aktualisasi karya penyelamatan Allah; mengerti tujuan hakiki dari pekabaran Injil; memiliki karakteristik yang baik sebagai seorang penginjil; memahami karakteristik masyarakat sasaran pekabaran Injil; dan melakukan metode kontekstualisasi yang tepat. Kelima aspek tersebut menghasilkan aplikasi yang dapat diajarkan oleh para gembala sidang GPdI di Wilayah Waropen Timur Papua kepada para pelayan Injil, sehingga dapat melakukan pekabaran Injil kepada suku Auri secara efektif. Tentu saja penelitian ini dapat dikembangkan untuk mengukur tingkat keberhasilan dari pengimplementasian strategi penginjilan yang telah diaplikasikan.

\section{Referensi}

Barclay, William. Pemahaman Alkitab Setiap Hari: Kitab Kisah Para Rasul, Jakarta: BPK Gunung Mulia, 2009.

Chamblin, J. Kox. terj. Irwan Tjulianto dan Elsye Elisabeth Rau. Paulus dan Diri, Surabaya: Momentum, 2009.

Dan Kia, A. "Kajian Teologis-Pedagogis Keteladanan Rasul Paulus dalam Penginjilan dan Relevansinya bagi Pendidik Kristen Masa Kini." Shanan Jurnal Pendidikan Agama Kristen 1, no. 2 (2017): 74-102. http://ejournal.uki.ac.id/index.php/shan/article/view/1493

Djaman, Komariah, Aan Satori. Metodologi Penelitian Kualitatif, Bandung: Alfabeta, 2010

Handako, Martin. Motivasi Daya Penggerak Tingkah Laku, Yogyakarta: Kanisius, 1992. Imanuel, Gilbert Yasuo, and Yogi Darmanto. "Pelayanan Lintas Budaya: Sebuah Kajian Tentang Pelayanan Rasul Paulus Dalam Kisah Para Rasul 16: 13-40." VOX DEI: Jurnal Teologi Dan Pastoral 1, no. 1 (2020): 78-89. https://jurnal.sttekumene.ac.id/index.php/VoxDei/article/view/18

MacArthur, John. The MacArthur Study Bible, USA: Thomas Nelson, 2006.

Poerwadarminta, WJS. Kamus Umum Bahasa Indonesia, Jakarta: Balai Pustaka, 1996.

Sariman, Silas. "Strategi Misi Sadrach Suatu Kajian yang Bersifat Sosio Historis."Jurnal ABDIEL 3, no. 1 (2019): 17-32. http://journal.stt-abdiel.ac.id/JA/article/view/34/22.

Shenk, Wilbert R. Mission Strategies, Grand Rapids: Michigan, 1993.

Siahaan, Harls Evan R. "Presuposisi Kitab Kisah Para Rasul Dalam Rancang Bangun Teologi Pentakosta." KURIOS (Jurnal Teologi dan Pendidikan Agama Kristen) 4, no. 1 (2018): 5673. https://e-journal.sttpb.ac.id/index.php/kurios/article/view/34/48

Siahaan, Harls Evan. "Karakteristik Pentakostalisme Menurut Kisah Para Rasul." Dunamis: Jurnal Teologi dan Pendidikan Kristiani 2, no. 1 (2017): 12-28.Tenney, Merril C. Survei Perjanjian Baru. Malang: Gandum Mas, 1993.

Siahaan, Harls Evan R. "Presuposisi Kitab Kisah Para Rasul Dalam Rancang Bangun Teologi Pentakosta.” Kurios 4, no. 1 (April 11, 2018): 56-73. Accessed April 20, 2018. http://www.sttpb.ac.id/e-journal/index.php/kurios/article/view/34/48.

Tomatala, Y. Penginjilan Masa Kini II, Gandum Mas Malang 1998.

Venema, H. Injil Untuk Semua Orang, Pembimbing ke Dalam Ilmu Misiologi, Jilid I. Jakarta: Yayasan Komunikasi Bina Kasih, 1997.

Wagner, Peter. Strategi Perkembangan Gereja, Malang: Gandum Mas, 2015.

Siahaan, Harls Evan. "Karakteristik Pentakostalisme Menurut Kisah Para Rasul." Dunamis: Jurnal Teologi dan Pendidikan Kristiani 2, no. 1 (2017): 12-28.

Widjaja, Fransiskus Irwan. Misiologi Antara Teori, Fakta Dan Pengalaman. 1st ed. Yogyakarta: Andi Offset, 2018. 
Widjaja, Fransiskus Irwan. "Papua Dan Panggilan Macedonia Di Zaman Millennium Baru." DIEGESIS: Jurnal Teologi Kharismatika 2, no. 1 (2019): 35-38.

Widjaja, Fransiskus Irwan, Daniel Ginting, and Sabar Manahan Hutagalung. "Teologi Misi Sebagai Teologi Amanat Agung.” THRONOS: Jurnal Teologi Kristen 1, no. 1 (2019): $17-24$. 